\title{
A Caring heart program enhancement in Ondo State through augmented E-Government implementation Code:[S43NH33]
}

\author{
Adegboye Adegboyega ${ }^{1}$, Mamidu Aruna Ishola ${ }^{2}$, Adu Babafemi Ojo ${ }^{3}$ \\ ${ }^{1}$ Dept .of Maths/Statistics/Computer \& Information System, Achievers University, Owo ,Ondo State, Nigeria \\ ${ }^{2}$ Dept. of Accounting, Achievers University, Owo, Ondo State, Nigeria \\ ${ }^{3}$ Dept. of Business Administration, Achievers University, Owo, Ondo State, Nigeria
}

\section{Email address:}

akanbi2090@yahoo.co.uk (A. Adegboyega), isolaaruna@yahoo.com (M. A. Ishola), babafemiadu2003@yahoo.co.uk (A. B. Ojo)

\section{To cite this article:}

Adegboye Adegboyega, Mamidu Aruna Ishola, Adu Babafemi Ojo. A Caring Heart Program Enhancement in Ondo State through Augmented E-Government Implementation Code:[S43NH33]. Internet of Things and Cloud Computing. Vol. 2, No. 4, 2014, pp. 17-25.

doi: $10.11648 /$ j.iotcc. 20140204.11

\begin{abstract}
This study appraised e-Government implementation in Ondo state government ministries, agencies and departments. It determined the availability of e-Government resources and infrastructure, the stage of e-government implementation and the challenges. Siau and Long, 2005 five phase of e-Government model was used for analysis. Survey design approach was adopted. Data were collected with a structured questionnaire administered to the Director of IT and administrators in the ministries, agencies and departments, result shows $96.42 \%$ participation. Collected data were structured into grouped frequency distributions. Findings revealed that Ondo state had made an entrance into e-Government. Resources and infrastructure for e-Governance were available and the State was found to be at the second phase (interaction) of eGovernment process and has not effectively demonstrated its capacity to progress towards the higher phases of e-government. The study indentified factors that inhibit the implementation of e-Government in Ondo state and recommended how egovernment implementation can be further improved in order to accomplished various present and future government programs and delivered the present and future expectation of citizen, Ondo state vision 20: 2020 and make it a truly Sunshine state. This research work is done using Ondo state as study case; it can be apply to any state in developing countries.
\end{abstract}

Keywords: E-Government, Information and Communication Technology (ICT), E-Government, A Caring Heart, Ondo State Vision20: 2020

\section{Introduction}

E- Government" refers to the use by government agencies of information technologies (such as wide area network, the internet and mobile computing) that have the ability to transform relations with citizens, businesses and other arms of government. These technologies can serve a variety of difficult ends: better delivery of government services to citizens, improved interactions with business and industry, citizen empowerment through access to information, or more efficient government management. The resulting benefits can be less corrupt, increased transparency, and cost reduction [3].The implementation of e-Government on the government sector is a must as it gives huge benefits. [2]

E-government does not create good governance, but good governments use it to improve their governance Ifinedo [10].
It has the potential of renovating public services, as well as reengineering the fundamental relationship between government and citizen [7, 11, 13]. Increasingly, advances in ICT have accelerated the growth of e-government in both the developed and developing countries around the world $[1,6]$. Countries such as the United States, Canada, and Australia lead in the deployment of e-government $[1,15,16]$, and many other governments around the world are making serious efforts to join them [15].

Governments around the world are at various stages of eGovernment readiness and implementation as confirmed by the United Nations e-Government readiness reports with European countries generally taking the top spots, in 2014, ranking Nigeria has E-Government Development Index EGDI Middle (Between 0.25 and 0.50). The UN global egovernment readiness index (UN egovernment survey, 2014; is a composite index comprising the Web measure index, the 
telecommunication infrastructure index and the human capital index. Nigeria's government has come to realize the fact that no economy can be sustained without the integration of ICT with its development strategy and has adopted this technology towards the growth of its economy by declared ICT a national priority in the year 2001, resulting in the formulation of a policy for Information Technology in 2001.The enabling law of the National Assembly known as the National Information Technology Development Act of 2007 was later enacted formally establishing the National Information Technology Development Agency (NITDA) and empowering it to plan, develop and promote the use of Information Technology in Nigeria. Although the implementation of e-Government has begun in Nigeria, there is little evidence or research to suggest that a clear framework for the adoption of e-Government is being followed. According to Yusuf [17].Most government websites are in the publish stage and very few are at the transact stage. Findings from a recent study by Mundi and Musa [5] showed that only $30 \%$ of the Nigerian state websites could be described as having reached the second stage of eGovernment and $70 \%$ of them were still very much in the publish stage of e-government. These states were Lagos and Imo and the Federal Capital Territory, Abuja. They provided services that invite citizens to interact with them such as message boards and conversation forums. They also provided facilities for users to give online feedback. Ondo State, the "Sunshine State", was created from the defunct Western Region on 3rd February, 1976. Before its creation, the state existed as the Ondo Province of the old Western Region. The State covers a land area of 14,793 square kilometers with its administrative capital at Akure. The population of the state as revealed by the Year 2006 population is $3,441,024$.

The state has launched an official website and most of its agencies, ministries and departments (MDAs) have email addresses to communicate with customers. Some restraining factors have been found to affect successful application of eGovernment in Nigeria. These include: unreliable electricity supply, low Internet distribution, low adult literacy rate, etc [4]. What does this imply for e-government in the state? What is the level of the expectation of Ondo citizens towards e-Government? What are the e-Government services available and at what stage of e-Governance is the state in? Accordingly, this research work intend to addressed these gaps by applying Siau and Long, 2005 five phase of e-Government model. The model suggested the five critical phases of egovernment evolution, viz. web presence, interactions, transactions, transformation and E-democracy. In order to gain knowledge necessary for accomplishing the stated objectives; the following research questions guided the study:

1. What e-Government resources and infrastructure is available in Ondo state government ministries, agencies, and departments?

2. What is the stage of e-Government implementation in Ondo state ministries agencies and department?

3. What are the constraints of e-Government adoption in
Ondo state government ministries, agencies and departments?

4. What policy intervention will be pivotal for effective implementation of e-Government in Ondo State?

Therefore, it is imperative to assess problems and challenges facing e-Government implementation in Ondo State and suggests solutions to how e-Governance can be used to improve the state program "A Caring Heart" transformation agenda, across all sectors of the state and adequately consider and satisfactory meet up the needs and aspirations of Ondo state citizens. This is the basis of this research work.

\section{2. "A Caring Heart" Philosophy}

On assumption of office in 24/02/2009, Dr Olusegun R Mimiko, the Governor of Ondo State, launched a 12 point agenda with the acronym 'a caring heart'. The points are: 1 Agriculture, 2 Community driven City, 3. Aggressive Capitalization of our Land 4 Roads and Infrastructures, 5 Industrialization, 6 No to Poverty Programme, 7 Gender Equality and Women Empowerment, 8 Health Care and Housing, 9 Education and Capacity Building, 10 Artisanship Development and Empowerment Programme, 11 Rural Development, 12 Tourism, Sport and Youth Development

The Vision: "To make Ondo State the best administered state in Nigeria and the cynosure of all eyes which all its citizens shall be proud of; where equity, justice and fairness shall be the driving forces of governmental action".

Mission Statement:"To mobilize the people of Ondo State to harness all our God-given resources, create and use wealth for the ends of individual happiness, collective fulfillment and peaceful collaboration in an environment of transparent and honest leadership".[ 9]

The focus of this research paper is the gaps e-government implementation in the state needs to fill and improvement needed so that the practical meaning of the acronym will affects positively all sectors of the state and adequately meet up the needs, aspirations of Ondo state citizens and make it a truly Sunshine state.

\subsection{E-Government and E-Governance}

E-governance is beyond the scope of e-government. While e-government is defined as a mere delivery of government services and information to the public using electronic means, e-governance allows citizen direct participation of constituents in political activities going beyond government and includes E-democracy, E-voting and participating political activity online. So, most broadly, concept of Egovernance will cover government, citizens' participation, political parties and organizations, Parliament and Judiciary functions.

\section{Research Framework}

The study adopted Siau and Long, 2005 five phase of eGovernment model for analysis. Siau and Long, 2005 research [14] classified e-Government into five distinct phases. The Siau 
and Long, 2005 Five Phases of E-Government model demonstrated the progression of e-government in the connected environment, and identified strategy and other factors that contribute to success in each phase. The phases are:

Presence: This stage is classified by a simple informationproviding Web site of a passive nature, sometimes described as "brochure ware," indicating the same level of functions as a paper brochure. It represents the simplest and least expensive entrance into e-government, but it also offers the fewest options for citizens. A typical example is a basic Web site that lists cursory information about an agency, such as hours of operation, mailing address, and/or phone numbers, but has no interactive capabilities.

Interaction: The second stage is interaction. Although interactive Web-based initiatives offer enhanced capabilities, efforts in this group are still limited in their ability to streamline and automate government functions. Interactions are relatively simple and generally revolve around information provision. These types of initiatives are designed to help the customer avoid a trip to an office or make a phone call by making commonly requested information and forms available around the clock. These resources may include instructions for obtaining services, downloadable forms to be printed and mailed back to an agency, or perhaps e-mail contact to respond to simple questions. The interaction stage offers simple interactions between government and citizen (G2C), government to business (G2B), or government agency to government agency (G2G).

Transaction: The third stage in the evolution of egovernment initiatives is transaction. These initiatives are more complex than simple information provision and embody the types of activities popularly associated with egovernment. They enable clients to complete entire tasks electronically at any time of the day or night. These initiatives effectively create self-service operations for tasks such as license renewals, paying taxes and fees, and submitting bids for procurement contracts. Although the level of interactivity is of a higher magnitude than second stage initiatives, the activities still involve a flow of information that is primarily one-way (either to government or to the client, depending on the activity). The electronic responses are generally highly regularized and create predictable outcomes. The transaction stage enables transactions such as paying for license renewals online, paying taxes or fees, or submitting bids for procurement contracts.

Transformation: The highest order of evolution for egovernment initiatives is transformation. Initiatives at this level utilize the full capabilities of the technology to transform how government functions are conceived, organized, and executed. Such initiatives would have the robust customer relationship management capabilities required to handle a full range of questions, problems, and needs. One of the distinctions of these initiatives is that they facilitate the seamless flow of information and collaborative decision making between federal, state, local, public, and private partners. In other words, transformative eGovernment initiatives often seek to remove the organizational barriers that promote agency-centric solutions and, instead, promote customer-centric solutions. Some advocates suggest that, at its most advanced level, egovernment could potentially reorganize, combine, and/or eliminate existing agencies and replace them with virtual organizations. The highest stage, most closely aligned with the concept of governance, involves a reinvention of how government functions are conceived and organized.

E-democracy: E-government gradually changes the way in which people make political decisions.

The integration process when it is reaching its maturity leads to the emergence of e-society. The e-Society can be broadly defined as one that uses digital media in most relationships: peer to peer (personal communications, business to business purchases etc.); government to other (government online); other to government (voting/governance); peer to other (business to consumer, etc.). Electronic government is very flexible when compared to the traditional government which is highly bureaucratic in nature leading to undue delay. So, esociety will be ideal for the people with better ways provided by e-government with the use of information and technologies in Public Administration combined with organizational changes and new skills which help to improve the public service and democratic processes.

\section{Instrument for Data Collection}

A sample frame comprising 45 Ondo state government organizations was used. A total enumeration of all the state government ministries, agencies and departments in Ondo state was carried out. The purposive sampling method was adopted in selecting the respondents so as to ensure that selected individuals were those that had adequate knowledge of the Ondo state e-Government practices. The Directors of Information Technology or their representatives were the primary respondents.

Data were collected with a structured questionnaire designed based on the Siau and Long, 2005 five phase of egovernment model. It was adapted from Siau and Long, 2005 Five phase of e-Government model. The instrument, designed in a five point like scale, comprised five sections: Section A elicited information about ministries, agencies and departments such as name of ministry/agency/department. Section B asked questions about e-Government resources available in each ministries/agencies/department while section $\mathrm{C}$ sought to ascertain the stage of e-government in Ondo state using Siau and Long, 2005 five phase of eGovernment model. Section D, the last section, contained questions that enquired about the challenges encountered by the ministries/agencies/departments in e-Government adoption and implementation processes. The instrument was validated through face and content validity. It was subjected to thorough scrutiny by three experts in e-government research and two others in the field of information science. Modifications were made on the instrument based on their 
assessments. Copies of the questionnaire were distributed to the respondents by the researchers who had initially sought the permission of the permanent secretaries and head of the various government organizations. A total of 140 copies of the questionnaire were distributed but 135 copies were completed and returned. This constituted $96.42 \%$ and was used for data analyses.

\subsection{Data Analysis}

The data collected were subjected to descriptive statistical analysis in relation to the research questions. Statistical
Package for Social Science (SPSS) software was used to carry out the analysis. The variables used to assess eGovernment adoption in Ondo state using 4-point like scale were re-coded. Strongly Agree and Agree was e re-coded as Agree while Disagree and Strongly Disagree was re-coded as Disagree. Next, a frequency distribution tables was generated for all variables.

\section{Results}

\subsection{Available E-Government Resources and Infrastructure}

Table 1. Available E-Government Resources \& Infrastructure

\begin{tabular}{|c|c|c|c|c|c|}
\hline & \multicolumn{3}{|l|}{ RESPONSE } & \multicolumn{2}{|l|}{ RESPONSE } \\
\hline & AVAILABLE \% & NC & $\%$ & AVAILABLE \% & NOT AVAILABLE \% \\
\hline Desktop computers & 97 & 3 & DSTV & 59 & 41 \\
\hline Laptop Computers & 82 & 18 & Recording Studio & 36 & 64 \\
\hline Palmtop computers & 54 & 46 & Video Recorders & 70 & 30 \\
\hline Printers & 89 & 11 & Video Cameras & 71 & 29 \\
\hline Scanners & 67 & 33 & Digital Cameras & 74 & 26 \\
\hline PABX(intercom) & 51 & 49 & TV sets & 66 & 34 \\
\hline Office Mobile Phones & 57 & 43 & Fax Machine & 40 & 60 \\
\hline GSM & 66 & 34 & E-mail & 76 & 24 \\
\hline CDMA & 39 & 61 & Internet & 75 & 25 \\
\hline Walkie-Talkies & 31 & 69 & Website/web Portal & 77 & 23 \\
\hline Close Circuit & 46 & 54 & Video Conferencing & 43 & 57 \\
\hline TV & 71 & 29 & Teleconferencing & 40 & 60 \\
\hline Radio & 70 & 30 & VSAT Satellite terminal & 47 & 53 \\
\hline
\end{tabular}

Table 2. Results of the analysis of the stage of e-government implementation in Ondo state (Continued up to next page)

\begin{tabular}{|c|c|c|c|}
\hline \multirow{2}{*}{ Web Presence } & \multicolumn{3}{|c|}{ Response \% } \\
\hline & Agree & Disagree & Don't know \\
\hline My agency/Ministry/dept has its own official website & 53 & 40 & 7 \\
\hline My agency/Ministry/dept use the same website as state website & 35 & 54 & 11 \\
\hline Our official website comprise downloadable forms & 42 & 40 & 19 \\
\hline Stakeholders can visit our website to obtain a handful of information about my agency/Ministry/dept & 57 & 36 & 7 \\
\hline Online services or information is available for tourists & 44 & 34 & 21 \\
\hline The head of my agency/Ministry/dept was consulted before the state website was launched & 34 & 31 & 35 \\
\hline Online services are available for citizen to govt transaction & 53 & 29 & 18 \\
\hline Online services are available for $\mathrm{G} 2 \mathrm{C}$ transactions & 16 & 30 & 54 \\
\hline Interaction & Agree & Disagree & Don't know \\
\hline Complains can be made online & 50 & 30 & 19 \\
\hline E-mail contact to respond to simple questions is readily available to stakeholders & 46 & 41 & 13 \\
\hline Stakeholders can download forms to be printed and mailed back to my agency/ministry/department & 47 & 38 & 15 \\
\hline Instructions for obtaining services offered by my agency/ministry/dept is available online & 41 & 42 & 18 \\
\hline Transaction & Agree & Disagree & Don't know \\
\hline Taxes can be paid online & 42 & 35 & 24 \\
\hline There is a working database that supports online transaction & 43 & 37 & 20 \\
\hline Building permit can be booked online & 31 & 35 & 34 \\
\hline License renewals can be done online & 36 & 40 & 24 \\
\hline Submission of bids for procurement contracts are done via my agency e-mail add & 36 & 42 & 22 \\
\hline Transformation & Agree & Disagree & Don't know \\
\hline Local sys are linked to higher level sys within similar functionally & 33 & 30 & 37 \\
\hline Sys are networked/integrated across diff functions & 45 & 38 & 17 \\
\hline Collaborative decision making btw our federal partners and my ministry & 42 & 24 & 33 \\
\hline
\end{tabular}


Table 1 presents the E-government Resources \& Infrastructure available in Ondo state.

Desktop computers, Laptop Computers, Printers, and Photocopiers accounted for more than $80 \%$, Video Recorders, Video Cameras, Digital Cameras, E-mail, Internet, TV, Radio and Website/web Portal accounted for more than $70 \%$, Scanners, GSM, TV sets accounted for $60 \%$, while Palmtop computers, PABX (intercom), Office Mobile Phones, DSTV, accounted for 50\%,VSAT Satellite terminal, Teleconferencing, Video Conferencing, WalkieTalkies, Close Circuit, NITEL Phones, CDMA, Recording
Studio, VCD Player and Fax Machine accounted for less than $50 \%$,of e-Government resources and facilities available in ministries/agencies/departments (MDAs) in Ondo state. This is a good development and government should keep it up. However, to further empower the MDAs efficiency and effectiveness of ICT data processing and service delivery couple with ease of data management and storage, it necessary to improve percentage of e-government resource and infrastructure accounted for less than $60 \%$.

\subsection{Concluding Data}

Table 3. Results of the analysis of Constraints of e-government implementation in Ondo state

\begin{tabular}{|c|c|c|}
\hline \multirow{2}{*}{$\begin{array}{l}\text { Infrastructural Constraints } \\
\text { Infrastructural Constraints } \\
\end{array}$} & \multicolumn{2}{|c|}{ Responses \% } \\
\hline & HIGH & LOW \\
\hline Inefficient electricity supply & 67 & 33 \\
\hline Bandwidth inadequacy & 55 & 45 \\
\hline Low internet access for citizens and employees & 60 & 40 \\
\hline Inefficient comm. Channels & 60 & 40 \\
\hline Cost ,time and effort required to re-engineer work process & 63 & 37 \\
\hline Insufficient ICT infrastructure across the state & 64 & 36 \\
\hline Economic constraints & High & Low \\
\hline Diversion of funds for e-govt & 53 & 47 \\
\hline Underfunding of e-govt projects & 59 & 41 \\
\hline Budgetary constraints & 58 & 42 \\
\hline High cost of purchasing/replacing e-govt resources & 56 & 44 \\
\hline \multicolumn{3}{|l|}{ Cultural Constraints } \\
\hline Irregular training of govt officials on ICT use & 61 & 39 \\
\hline Poor maintenance culture & 66 & 34 \\
\hline Strategy of internal leadership & 47 & 53 \\
\hline Inadequate training of ICT engineers and prog & 61 & 39 \\
\hline Organizational culture that don't support change & 53 & 47 \\
\hline Legal constraints & High & Low \\
\hline Lack of state ICT & 56 & 44 \\
\hline Lack of a legal framework to guide e-govt practice & 62 & 38 \\
\hline Lack of org laws, registration, and policies that accept paperless transactions & 60 & 40 \\
\hline Lack of enabling law encompassing privacy and security of data & 59 & 41 \\
\hline Inadequate legal sanction of new forms of storage and archiving & 62 & 38 \\
\hline Individual/human factors & High & Low \\
\hline Low level of awareness about e-govt & 63 & 37 \\
\hline Poor attitude of data by and statistics among employees & 61 & 39 \\
\hline Fear of transparency that e-govt could bring & 59 & 41 \\
\hline Insufficient knowledge and skills on the use of internet & 63 & 37 \\
\hline Resistance to change from traditional ways of doing things & 61 & 39 \\
\hline Low level of skills on e-govt resource use & 60 & 40 \\
\hline
\end{tabular}

Table 4. Results of the distribution constraints of e-government implementation in Ondo state

\begin{tabular}{|c|c|c|c|c|c|c|c|c|c|c|c|}
\hline \multicolumn{4}{|c|}{ Infrastructural constraints } & \multirow{2}{*}{\multicolumn{2}{|c|}{$\begin{array}{l}\text { Economic Constraints } \\
\text { Freq \% }\end{array}$}} & \multirow{2}{*}{\multicolumn{2}{|c|}{$\begin{array}{l}\text { Cultural Constraints } \\
\text { Freq \% }\end{array}$}} & \multirow{2}{*}{\multicolumn{2}{|c|}{$\begin{array}{l}\text { Legal Constraints } \\
\text { Freq \% } \\
\end{array}$}} & \multirow{2}{*}{\multicolumn{2}{|c|}{$\begin{array}{l}\text { Human Factors } \\
\text { Freq. } \%\end{array}$}} \\
\hline & & Frec & & & & & & & & & \\
\hline \multirow[t]{3}{*}{ Valid } & Low & 52 & 38.64 & 58 & 43 & 57 & 42 & 54 & 40 & 53 & 39 \\
\hline & High & 83 & 61.36 & 77 & 57 & 78 & 58 & 81 & 60 & 82 & 61 \\
\hline & Total & 135 & 100 & 135 & 100 & 135 & 100 & 135 & 100 & 135 & 100 \\
\hline
\end{tabular}

A Web Presence

Table 2 shows the Web presence stage of e-Government maturity in Ondo State. (53\%) government organizations have official websites while $35 \%$ use the same website as state official website. This suggests that the technology associated with Web presence stage of e-Government as reported by Siau and Long, 2005 research is readily available in Ondo state. The table shows $42 \%$ indicated that their organization websites comprise downloadable forms while $57 \%$ related that stakeholders can visit their website and 
obtain information about their respective organizations. $44 \%$ accounted that online information is available to tourists. This implies that the process involved in the web presence stage of e-Government is in place in Ondo although it cannot be said to be fully mature

\section{B Interaction}

From Table 2 which depicts Siau and Long, 2005 interaction phase of e-Government, $50 \%$ of the organizations have facilities for complaints being made online, $46 \%$ have email contacts to respond to questions. However $46 \%$ have opportunities for stakeholders to download forms to print and mail back to these organizations while $41 \%$ have instructions online for obtaining services offered.

\section{Transaction}

The transaction phase activity of e-Government in Ondo state is very low compare to expectation. Most organizations have working databases that support online transaction which suggests a good foundation for further transactions in the future. However, transactions such as online payment of taxes, online building permits, and online renewal of licenses and submission of bids for online procurement of contracts have low percentages less than $45 \%$. This may suggest that although the technology involved in the interaction phase is moderately available there is a major gap in its actualization in relation to the transaction activities and processes of eGovernment adoption.

\section{Transformation}

The transformation phase involves a state where there is full adoption of e-Government statutes and policies. It is the highest order of evolution of e-Government initiatives and initiatives at this phase utilise the full capabilities of the technology to transform how government functions are conceived and executed. Most local systems are not linked to higher level systems within similar functionality accounted for $33 \%$, most systems are not integrated across different functions accounted for $45 \%$, while collaborative decisions between Federal and state departments are not wellestablished, it accounted for only $42 \%$.

\section{E E-democracy}

E-government gradually changes the way in which people make political decisions. It is the use of ICT to support the participation of citizen in democratic decision making, such as elections, petitions, referendums and campaigns. The introduction of this new form citizen's participation is considering an important element in the modernization of democratic institution and social inclusion. Due to inherent inadequate facilities in transaction and transformation stage of Ondo state e-government implementation this cannot meaningfully archived now.

\subsection{Challenges of E-Government in Ondo State}

Table 3 presents the results of the constraints hindering egovernment adoption in Ondo state.

Infrastructural constraints

Table 3 presents the result of the analysis on infrastructural constraints encounter by Ondo state ministries/agencies/departments. Inefficient electricity supply, low internet access for citizens and employees, inefficient comm. Channels, inefficient comm. Channels, Cost, time and effort required to re-engineer work process and insufficient ICT infrastructure across the state topped the list of infrastructural challenges faced by Ondo state government organizations, not less than $60 \%$ of Ondo state government organizations are confronted by this above named impediments while Bandwidth inadequacy accounted for $55 \%$.

\section{Economic constraint}

Table 3 shows that Diversion of funds for e-govt, Underfunding of e-govt projects, budgetary constraints and high cost of purchasing/replacing e-govt resources accounted not less than $53 \%$ for economical constraint.

\section{Cultural constraints}

As shown in Table 3, Irregular training of govt officials on ICT use, Poor maintenance culture and inadequate training of ICT engineers and program accounted for more than $60 \%$ for cultural constraints, followed by Organizational culture that don't support change 53\% and Strategy of internal leadership $47 \%$ respectively.

\section{Legal Constraints}

Lack of a legal framework to guide e-govt practice, inadequate legal sanction of new forms of storage and archiving, and lack of org laws, registration, and policies that accept paperless transactions accounted for $62 \%, 62 \%$ and $60 \%$ respectively. Lack of state ICT 56\% and lack of enabling law encompassing privacy and security of data accounted for $59 \%$.

\section{Individual/human factors}

The least individual/personal constraint in the implementation of e-Government in Ondo state was the fear of transparency that e-Government could bring in the ministries/agencies/departments this accounted for 59\%. In addition, low level of skills on e-government resource use, insufficient knowledge and skills on the use of Internet and resistance to change from traditional ways of doing things were also identified as major human constraints with not less than $60 \%$.

\subsection{Distribution of the Constraints}

Additional results are presented in Table 4.It shows the distribution of constraints. Infrastructural constraint $(61.36 \%)$ posed the greatest challenge to the adoption of eGovernment in Ondo state followed by Human Factor constraint with $61 \%$, legal constraint had $60 \%$. However, economical constraint and cultural constraint posed the least challenge to the adoption of e-Government in Ondo, with $57 \%$ and $58 \%$ respectively.

\section{Discussion of Findings}

In this section, some of the findings from this study were discussed in line with the research questions that guided the study.

Research Question 1: What e-Government resources and infrastructure is available in Ondo state government 
ministries, agencies, and departments?

The study reveals that majority of Ondo State government ministries/agencies/departments have the following eGovernment resources and infrastructure namely:

Desktop computers, Laptop Computers, Printers, and Photocopiers accounted for more than $80 \%$, Video Recorders, Video Cameras, Digital Cameras, E-mail, Internet, TV, Radio and Website/web Portal accounted for more than $70 \%$, Scanners, GSM, TV sets accounted for $60 \%$, while Palmtop computers, PABX (intercom), Office Mobile Phones, DSTV, accounted for 50\%,VSAT Satellite terminal, Teleconferencing, Video Conferencing, Walkie-Talkies, Close Circuit, NITEL Phones, CDMA, Recording Studio, VCD Player and Fax Machine accounted for less than $50 \%$,of e-Government resources and facilities available in ministries/agencies/departments (MDAs) in Ondo state. This is similar to a study done by [8] in which nearly all government organizations in south west region of Nigeria (more than $80 \%$ ) had access to computers. This reveals that the resources available for e-Government in Ondo state are available and working. This is a good development and government should keep it up. However, to further empower the MDAs efficiency and effectiveness of ICT data processing and service delivery couple with ease of data management and storage, it necessary to improve percentage of e-government resource and infrastructure accounted for less than $60 \%$.This would increase MDAs proficiency, productivity and overall productivity to the Ondo state program title "A Caring Heart".

Research Question 2: What is the stage of e-Government implementation in Ondo state ministries agencies and department?

Table 2 shows the Web presence stage of e-Government maturity in Ondo State. (53\%) government organizations have official websites while $35 \%$ use the same website as state official website. This suggests that the technology associated with Web presence stage of e-Government as reported by Siau and Long, 2005 research is readily available in Ondo state. The table shows $42 \%$ indicated that their organization websites comprise downloadable forms while $57 \%$ related that stakeholders can visit their website and obtain information about their respective organizations. $44 \%$ accounted that online information is available to tourists. This implies that the process involved in the web presence stage of e-Government is in place in Ondo although it cannot be said to be fully developed. The Ondo state Web presence phase highlighted in this study is in keeping with [17], work on e-Government activity in Nigeria. He noted that most government websites were in the publish stage (which is equivalent to presence phase) and a few government MDAs are at the transaction stage. A Caring Heart Program can be further enhanced by the MDAs, if government improved the web presence stage at least by $60 \%$. According to UN eParticipation framework DESA,(2007), this improvement will leads to e-Information, this will promote and maintain virtual public space that enables an individual voice to develop into a community (public) voice and help government to address, the challenge of how to listen, and respond appropriately to each individual contribution.

Research Question 3: What are the constraints of eGovernment adoption in Ondo state government ministries, agencies and departments?

Infrastructural constraints -Table 3 presents the result of the analysis on infrastructural constraints faced by Ondo state ministries/agencies/departments. Inefficient electricity supply, Low internet access for citizens and employees, Inefficient comm. Channels, Cost, time and effort required to re-engineer work process and Insufficient ICT infrastructure across the state topped the list of infrastructural challenges faced by Ondo state government MDAs, not less than $60 \%$ of Ondo state government MDAs are confronted by this above named impediments whereas Bandwidth inadequacy accounted for $55 \%$.

This is in line with a related study carried out by [8] from which poor infrastructure such as bandwidth inadequacy and incessant cut in public electricity supply were found to be major issues militating against the success of the eGovernment in south western Nigeria. [8] Listed the challenges hindering e-government in developing countries, among which is infrastructural constraint. He identified lack of state informational infrastructure and low internet access for citizens and employees as other major infrastructural constraint in developing countries.

Intermittent and total blackout of electricity power is national issue only God and good conduct of power supply authority and stake holder in energy sector can help Nigeria out, if government can monitor this there will be enough electricity power for all in Ondo state. Increasing cooling system of transformer using fan and air conditioning can make some transformer to serve better. Bandwidth should be increase to $80 \%$ in order for government to better inform her citizen.

Cultural constraints- As shown in Table 3, Irregular training of govt officials on ICT use, Poor maintenance culture and inadequate training of ICT engineers and program accounted for more than $60 \%$ for cultural constraints, followed by Organizational culture that don't support change 53\% and Strategy of internal leadership $47 \%$ respectively. [5] Established that poor maintenance culture is part of the barrier that the country must overcome to attain the implementation of mature e-Government development in Nigeria. Government is encouraged to improve the deficiency listed above in order for her program to have continuous flow and produced anticipated output that improve living standard of Ondo citizen.

Legal Constraints-Lack of a legal framework to guide egovt practice, inadequate legal sanction of new forms of storage and archiving, and lack of org laws, registration, and policies that accept paperless transactions accounted for $62 \%, 62 \%$ and $60 \%$ respectively. Lack of state ICT $56 \%$ and lack of enabling law encompassing privacy and security of data accounted for 59\%. [5] Identified the above constraints as inimitable challenges to developing countries like Nigeria for full utilization of the opportunity e-governance can offers 
to good governance. The Ondo state law makers should tackle the above challenges, so that they can make significant contribution to the state program.

Economic constraint - Table 3 shows that Diversion of funds for e-govt, Underfunding of e-govt projects, budgetary constraints and high cost of purchasing/replacing e-govt resources accounted not less than $53 \%$ for economical constraint. Government should intelligently address the above lapses so that Ondo state may excel in economic growth, government services and opening up their economies to local and foreign competition.

Individual/human factors-The least individual/personal constraint in the implementation of e-Government in Ondo state was the fear of transparency that e-Government could bring in the ministries/agencies/departments this accounted for $59 \%$. In addition, low level of skills on e-government resource use, insufficient knowledge and skills on the use of Internet and resistance to change from traditional ways of doing things were also identified as major human constraints with not less than $60 \%$. The Ondo State Local Government Training School (LGTS) and higher institutions in Ondo state can design courses that take care of the above deficiency.

Research Question 4: What policy intervention will be pivotal for effective implementation of e-Government in Ondo State?

Like most other states in developing countries, Ondo State government is yet to have an established Transformation phase. In the context of Siau and Long, 2005 five phase of eGovernment, Ondo State is in the second phase (interaction) of e-Government process and has not been able to demonstrate its ability to progress towards the higher phases of e-government, i.e., 'transaction' followed by 'transformation' and 'e-democracy'. Inadequate Infrastructure such as erratic electricity supply, low internet access for citizens and employees and bandwidth inadequacy were found to be major issues militating against the success of e-Government implementation in Ondo State. It is necessary to have a policy for bandwidth optimization, government to provide stable electricity and also make arrangement for its sustainability in the state. Ondo state governments must address issues of globalization, availability of power/energy, Information and Communications Technology (ICT) and democracy to ensure their relevance. In Ondo state, the extents to which these are being attended to by government are comparatively not enough to make the state globally competitive. 'Ise takuntakun' in Ondo state should be a continuous exercise to accomplish her distinguished programs.

\section{Conclusion and Recommendations}

In the context of Siau and Long, 2005 typology of egovernment, Ondo State is in the second phase (interaction) of e-Government process and has not been able to demonstrate its ability to progress towards the higher phases of egovernment, i.e., 'transaction' followed by 'transformation'. The study established that there is a need to put in greater effort to facilitate the full adoption of e-government in Ondo state. Infrastructural constraints was denoted as a major clog in the wheels of e-Government success and as such, further inroads can only be achieved when primal resources are available and working. There is a need for a better technical review of the Ondo state website; the website must be updated such that the required information is made available and up to date. Governments may need to play a greater role in navigating effective policies to reduce access costs for mobile broadband; support private collaboration; encourage innovative business models that drive employment such as micro-work and outsourcing; and support ICT entrepreneurship. Connectivity and digital divide issues should also be given more attention in Ondo state, acknowledge the fact that rural locations need internet connectivity. Policymakers should explore e-government on a more fundamental level through adjusting legislation and policies to include technology in national development strategies and welcoming new ideas and ways of connecting with citizens. E-government goals are constantly evolving to meet emerging challenges and increase public value, emphasis should placed on deploying a portfolio of eservices that spans functions, business units and geographies, at varying local or urban levels, this will increased the value of service offers to citizens by effectively adopting disruptive technologies in an adaptive and scalable manner. Collaborative service delivery is unavoidable, where governments, citizens, civil society and the private sector often work together to innovate processes and leverage new technologies. In meeting multi-faceted sustainability challenges, of Ondo state program call 'A Caring Heart ', government should increasingly using open data and data analytics to improve accuracy in forecasting citizens' demand of public utilities and screen for irregularities in public procurement to lower its risks. Also predictive analysis should be used to identify issues before problematic scenarios develop and opinion analysis is deployed in engaging citizens in public consultation and decision-making processes. Ondo state governments at various levels should empower citizen of the state through expanding e-participation. This type of e-government implementation will accomplished various present and future government programs, delivered the present, future expectation of citizen and Ondo state vision 20: 2020.This will make Ondo a truly Sunshine state This research work is done using Ondo state as study case; it can be apply to any state in developing countries.

\section{References}

[1] Accenture, "High performance government", 2004, Available:http://www.accenture.com [Oct 8, 2014]

[2] Achmad Nizar Hidayanto, Yulia Razila Ningsih, Puspa Indah Sandhyaduhita, and Putu Wuri Handayani (2014) The Obstacles of the E-Government Implementation: A Case of Riau Province, Indonesia: Journal of Industrial and Intelligent Information Vol. 2, No. 2, June 2014 Pp 126-130. 
[3] Adesola S.O., Akintola K.A. (2008) Components Analyses of E-government Implementation in Nigeria. $9^{\text {th }}$ AICTTRA 3RD INTERNATIONAL CONFERENCE International Conference \& Annual General Meeting, Volume 20, pages 20-25.

[4] C.K. Ayo, and U. Ekong (2008) "e-Voting Implementation in Nigeria: Prospects and Challenges". In e-Government2008: Proceedings of the 8th European Conference on $e-$ Government held in Ecole Polytechnique, Lausanne, Switzerland, from 10-11 July 2008. Pp.34 -38.

[5] D. Mundy, and B. Musa (2010) "Towards a Framework for eGovernment Development in Nigeria", Electronic Journal of e-Government vol. 8, no. 2, 2010, pp. 148-162.

[6] J. Kaaya (2003) "Implementing e-government services in East Africa: Assessing status through content analysis of government Websites". Electronic Journal of e-Government, vol. 2, no. 1, 2003, pp. 39-54.

[7] J.M. Moon (2001) "The evolution of e-government among municipalities: Rhetoric or reality?" Public Administration Review, vol. 62, no. 4, 2001, pp. 424-433.

[8] O.M. Awoleye, O. Adeniran, W.O. Siyanbola, and R. Adagunodo (2008) "Assessment of e-Governance Resource Use in South-Western Nigeria". InICEGOV 2008, held in, Cairo, Egypt. From 1-4 December, 2008 pp. 154.

[9] Ondo State Vision 20: 2020 First Implementation Plan 2010 2013.

[10] P. Ifinedo (207) "Moving Towards E-Government in a Developing Society: Glimpses of the Problems, Progress, and Prospects in Nigeria", In Global E-government: Theory,
Applications and Benchmarking, L. Al-Hakim, Ed. Hershey PA: Idea Group Inc., 2007, pp. 148-166.

[11] R. Heeks (1999) "Reinventing government in the Information Age: International practice in IT-enabled public sector reform”, New York: Routledge, 1999.

[12] R.Heeks (2001) "Understanding e-governance for development" iGovernment Working Paper Series, no. 11, University of Manchester, Institute of Development Policy and Management, 2001.

[13] R.T. Watson, and B. Mundy (2001) "A strategic perspective of electronic democracy". Communications of the ACM, vol. 44, no. 1, 2001, pp. 27.

[14] Siau and Long (2005) Research, "Traditional ROI Measures Will Fail in Government", 2003. Available: http://www.Siau and Long, 2005.com/resources/116100/116131/traditional_roi.pdf [Oct 8, 2014]

[15] United Nations E-Government Survey 2014 Pp 16-18.

[16] W.D. Huang, J. Ambra, and V. Bhalla (2002) "Key factors influencingthe adoption of egovernment in Australian public sectors". In Proceedings of the 8th.Americas Conference on Information Systems, 2002.

[17] Yusuff, M. (2005) Information and Communication technology and education: Analysing the Nigerian national policy for information technology International Education Journal 6(3), 316-321. 